\title{
Kombinerte stillinger bygger bro mellom utdanning og praksis
}

Nyutdannede sykepleiere er ofte usikre i rollen som praksisveileder. Erfarne lærere og sykepleiere i

kombinerte stillinger i praksisfeltet kan gi hjelp og veiledning ved behov.

\section{Marta Grongstad}

Avdelingsleder

Det helsevitenskapelige fakultet, UiT Norges arktiske universitet

Kari Birkelund Olsen

Førstelektor

Det helsevitenskapelige fakultet, UiT Norges arktiske universitet

Tove Aminda Hanssen

Førsteamanuensis

Det helsevitenskapelige fakultet, UiT Norges arktiske universitet

Sykepleierutdanning

Kombinerte stillinger

Praksisstudie

Veiledning

Samarbeid

Sykepleien 2018106 (65022) (e-65022)

DOI: 10.4220/Sykepleiens.2018.65022

\section{Hovedbudskap}

De kombinerte stillingene har styrket samarbeidet mellom utdanning og praksis, og satt søkelyset på kvaliteten i sykepleierstudentenes læring i praksisstudier. Etablering av team hvor sykepleiere og lærere i kombinerte stillinger jobber sammen, har vært et av de viktigste tiltakene i satsingen. 
Sykepleierutdanningen ved UiT - Norges arktiske universitet etablerte i 2011 kombinerte stillinger innen sykepleie i samarbeid med Universitetssykehuset Nord-Norge (UNN). Vi har i etterkant hatt stor etterspørsel etter våre erfaringer fra andre utdanningsinstitusjoner og ønsker med denne artikkelen å belyse disse.

\section{Bakgrunn}

Helsetjenestene er i stadig utvikling som følge av nye og endrete behov i befolkningen, og dette har innvirkning på utdanningen av helsepersonell $(\underline{1}, \underline{2}, \underline{3})$. Bachelorutdanningen i sykepleie har i den nasjonale rammeplanen for utdanningen (4) krav om 50 prosent av studiet i praksis, og praksisfeltet er derfor en viktig arena for utdanningen.

Spesialisthelsetjenesteloven ( $\underline{5}$ ) fastslår at sykehusene i de regionale helseforetakene har undervisning som en av fire hovedoppgaver, og denne lovpålagte tjenesten utløser ressurser til foretakene. Noen av disse ressursene, som er $\varnothing$ remerket studentundervisning i praksis, er brukt til å finansiere de kombinerte stillingene, i tett samarbeid med Det helsevitenskapelige fakultet (Helsefak) ved UiT.

Både UNN og Helsefak har nedfelt i sine strategiplaner at undervisningssamarbeidet skal prioriteres og styrkes. Dette var en viktig føring da ordningen med kombinerte stillinger ble etablert.

\section{$\equiv$ «Undervisningssamarbeidet skal prioriteres og styrkes.»}

Etableringen av kombinerte stillinger ved de helsefaglige profesjonsutdanningene og profesjonsutdanningen $\mathrm{i}$ psykologi ble vedtatt på et felles ledermøte mellom UNN og Helsefak i november 2011. Totalt ble det opprettet 30 kombinerte stillinger med enten 10 eller 20 prosent stillingsressurs.

Hovedmålet med etableringen var å imøtekomme endringene i helsetjenesten, styrke samarbeidet mellom Helsefak og UNN om studentenes kliniske praksis og knytte ansatte i begge institusjoner tettere sammen for å fremme praksisnær undervisning og veiledning for studentene. Til sammen 8 studieprogram ble tildelt kombinerte stillinger, og per mai 2017 er det 37 kombinerte stillinger. 
Sykepleierutdanningen har fått tildelt totalt 17 kombinerte stillinger etter vedtak i felles ledermøte. Ti av de ansatte er sykepleiere som har sin hovedstilling ved UNN, og sju er lektorer ved sykepleierutdanningen. Dette utgjør samlet en stillingsressurs på 2,7 stillinger.

\section{Kvalitetsforbedringsmodell}

Utviklingen og utprøvingen av de kombinerte stillingene har fulgt trinnene i kvalitetshjulet eller det såkalte PDSA-hjulet ( plan, do, study, act), som er gjort kjent av Deming (6) og videreutviklet av Kunnskapssenteret til modellen vist i figur 1 ( 7). Modellen har fem faser: forberedelse, planlegging, utføring, evaluering og oppfølging.

Sirkelen illustrerer hvordan forbedringsarbeid er en kontinuerlig prosess. I arbeidet med kombinerte stillinger har vi beveget oss frem og tilbake mellom fasene i de ulike prosessene i arbeidet. Vi har også jevnlig siden oppstarten justert arbeidet på bakgrunn av evalueringer og tilbakemeldinger.

\section{Figur 1: Modell for kvalitetsforbedring (9)}

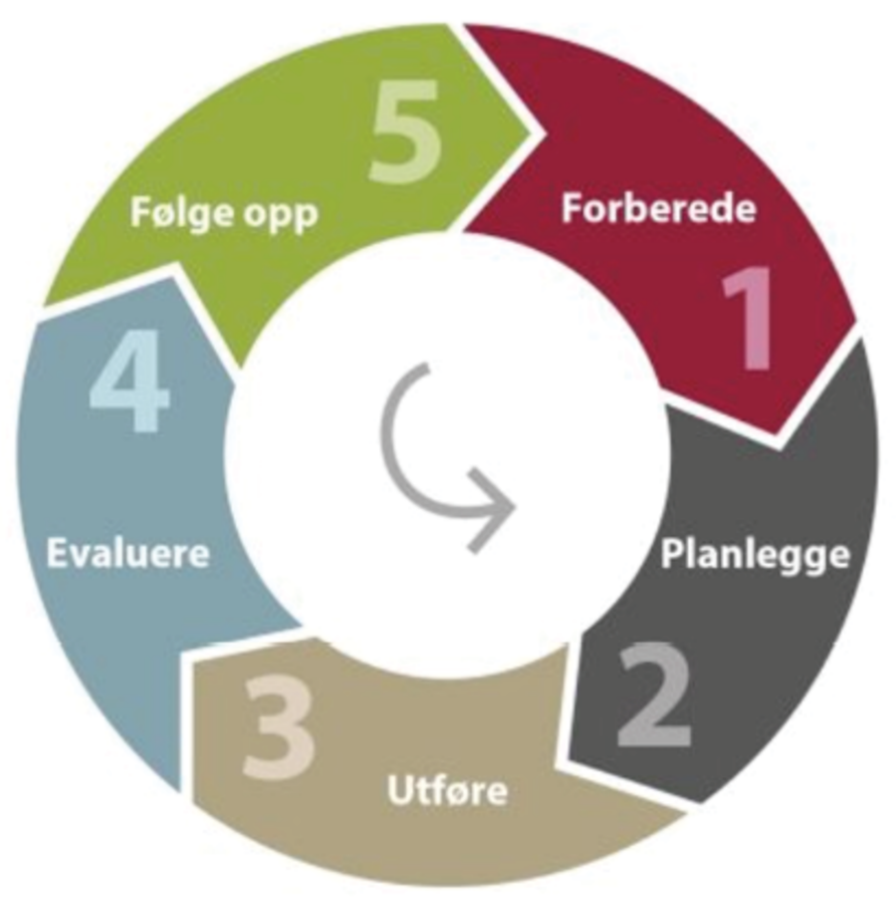


En viktig del av forberedelsen og planleggingen er at prosessen må ha forankring i ledelsen, hos medarbeiderne og i organisasjonen ( 7). Ved sykepleierutdanningen er arbeidet forankret i ledelsen ved utdanningen og ved UNN gjennom samarbeid med sykepleieledelsen ved de ulike klinikkene. Det var et viktig mål at stillingene skulle fordeles på mange personer for å skape en forankring også utover i organisasjonene.

Vi har prøvd ut flere modeller for tilrettelegging, veiledning og undervisning for studentene, hvor utvikling av deres læringsmiljø i praksisstudiene har stått sentralt. Flere evalueringsunders $\varnothing$ kelser er gjennomført, og det har vært kontinuerlig prosessevaluering gjennom innrapporteringer av aktivitet og dialog i erfaringsseminarer og nettverkssamlinger ( 8 , 9, 10). Utsagn fra muntlige evalueringer og tilbakemeldinger tas med i fortsettelsen for å illustrere erfaringer og resultater.

\section{Organisering}

Studieleder ved sykepleierutdanningen har hatt det overordnete lederansvaret og har samarbeidet nært med ledelsen ved fag- og forskningsavdelingen ved UNN. Sammen har de utarbeidet stillingsbeskrivelsene for de kombinerte stillingene. Styrking av kvaliteten på studentenes læringsmiljø og kunnskapsutveksling gjennom fag- og forskningsarbeid har vært en rød tråd i arbeidet.

Det ble etablert en ressursgruppe bestående av representanter for institusjonene og ansatte i kombinerte stillinger. Ressursgruppen har vært en pådriver for å etablere de ulike faglige og administrative ordningene som er nødvendige for å ivareta 17 personer i kombinerte stillinger. Gruppen arrangerte kvartalsvise møter det første året med ordningen, der ulike spørsmål og utfordringer ble fulgt opp.

\section{Veiledning}


En styrking av studentenes læring i løpet av praksisstudiene ble definert som det overordnete målet for arbeidet med de kombinerte stillingene innen sykepleie. I veiledning av studenter er både lærerveiledere og sykepleierveiledere sentrale. (Betegnelsen «lærerveileder» brukes om læreren fra skolen hvor studenten kommer fra; «sykepleierveileder» brukes om sykepleieren på praksisstedet som har ansvaret for den enkelte student.) De hjelper studentene med å knytte sammen teori og praksis samt tilrettelegger for læring og utvikling av klinisk kompetanse i praksisstudiene (므, 12, 13, 14).

Veilederne samarbeider om vurdering av studentenes kunnskaper, ferdigheter og kompetanse i tråd med studiets læringsutbyttebeskrivelser. Sykepleierveilederne har den kliniske kompetansen og tilgang til autentiske, kliniske læresituasjoner. Lærerveilederne har fagdidaktisk kompetanse som er viktig for å knytte studentenes konkrete, erfarte læresituasjoner til teoretisk kunnskap.

\section{三 «e kombinerte stillingene ble organisert i klinikkvise team.»}

Sykepleierveilederne og lærerveilederne har ulike, men komplementære kompetanseområder som er viktige for studentenes læring ( 14). En tydeliggjøring av både sykepleier- og lærerveileders rolle og ansvar, utvikling av nye modeller for veiledning av studentene og støtte til veilederne har vært sentrale deler av stillingsbeskrivelsen for de kombinerte stillingene.

Det ble bestemt at de kombinerte stillingene skulle organiseres i klinikkvise team (se figur 2). Hvert team ble satt sammen av en eller to sykepleiere og en lærer. Med utgangspunkt i teorien om at mennesker er i konstant utvikling, og at vi lærer gjennom å samhandle med verden og hverandre, er samarbeidskonteksten sentral ( $\underline{15}$ ). Samarbeid skapes ved at vi er sammen om noe, og relasjonene, situasjonene og de fysiske omgivelsene har betydning. Opprettelsen av team var viktig for at samarbeidet skulle nå ut i organisasjonen. 


\section{Team ved hver klinikk}

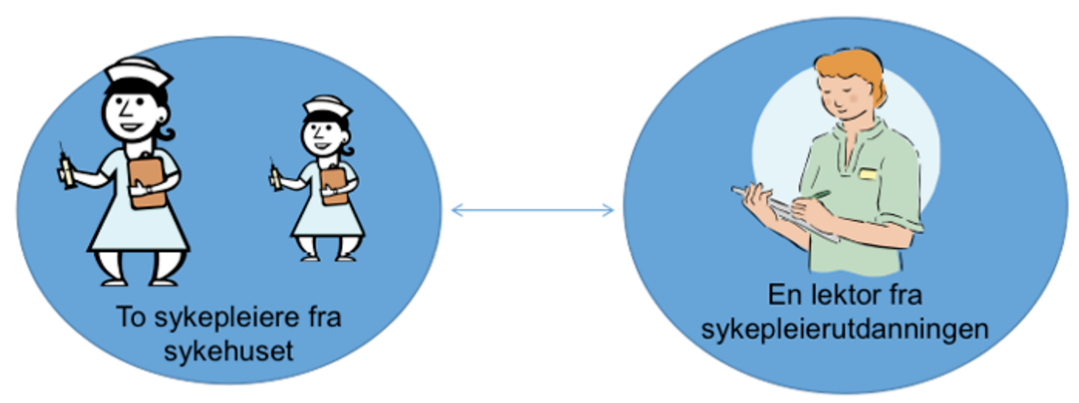

Teamene arbeidet tett sammen om arbeidsoppgavene som ble prioritert, og ble utfordret til å være i dialog med de ansatte ved klinikken og til å initiere møter med aktuelle samarbeidspartnere og ledere. Det har vært viktig å forankre planer og arbeidsoppgaver fortløpende i dialog med ledelsen ved utdanningen og klinikken.

I oppstartsfasen fikk de ansatte i kombinerte stillinger tilbud om et langsgående kurs i kunnskapsbasert praksis, undervisning og læring. Opplæring i kvalitetsforbedrende arbeid er vesentlig for at forbedringsarbeid skal føre til høyere kvalitet ( 7). Ulike fagseminarer, lærermøter i utdanningen, deltakelse på kurs og temadager har derfor vært viktige faglige tilbud for alle i teamene.

\section{Hva gjorde teamene?}

Ved oppstart fikk teamene i oppdrag å kartlegge klinikkenes behov og utfordringer for å identifisere og prioritere arbeidsoppgaver. Det kom her tydelig frem at de forskjellige klinikkene hadde ulike behov.

Alle teamene har vært involvert i praksiskoordinering og mottak av nye studenter. Sykehuset har over tid gjennomgått store endringer med omorganisering, sammenslåinger, mer dagbehandling, etablering av sykehotell og raskere utskriving av pasienter. Dette har medført færre sengeposter og færre innlagte pasienter, samtidig som antallet studenter $\varnothing$ ker. 
Grundig planlegging er viktig, og her har teamene vært sentrale. I tillegg har teamene arrangert ulike former for praksisseminarer både i for- og etterkant av studentenes praksisstudier, slik at læresituasjonene kan utnyttes optimalt.

\section{$\equiv$ «Grundig planlegging er viktig, og her har teamene vært sentrale.»}

En avdeling hadde for eksempel en fagutviklingssykepleier som ivaretok koordinering, veiledning og vurdering av sykepleierstudentene. Dette ble evaluert som en god ordning, og derfor ble arbeidsoppgavene som teamet skulle prioritere her, forskjellige fra de avdelingene som ikke hadde denne ordningen.

Noen team har jobbet spesifikt med å knytte tematikk fra teoriundervisningen sterkere til praksisstudiet. Flere avdelinger har lagt vekt på teori om systematisk, klinisk unders $\varnothing$ kelse og vurdering (16). Studentdrevne team, ansvar for ledelse og drift, og loggskriving i praksis ved bruk av relevante faglige refleksjoner er noen av områdene som de kombinerte stillingene har jobbet med.

\section{Støtte til veilederne}

Det har vært viktig å styrke veiledernes ansvar og rolle i praksisstudiet. Teamene har samarbeidet med lærerveilederne og sykepleierveilederne med tanke på studenter de har fulgt opp i praksis, og man har brukt tid på å drøfte felles problemstillinger og utfordringer. Teamene har også planlagt undervisningsbolker og annet program for studentene.

Både erfaring og forskning viser at sykepleiere som veileder studenter, føler seg skviset mellom ansvaret for pasientene og rollen som veileder ( 17 ). De kan føle seg usikre i veilederrollen og oppgir at de mangler pedagogiske kvalifikasjoner. Nyutdannete sykepleiere oppgir at de har behov for veiledning og støtte i veilederrollen (17).

\section{$\equiv$ ¿Sykepleiere som veileder studenter, føler seg skviset mellom ansvaret for pasientene og rollen som veileder.»}

Den jobben sykepleierveilederne gjør, har vist seg å ha betydning for studentenes læring i praksisstudiene ( $\underline{13}, \underline{18})$, og derfor har teamene prøvd ut flere måter å imøtekomme sykepleierveiledernes behov på. 


\section{Til stede i praksis}

Ved noen avdelinger har faste møter fungert bra. På andre, ofte st $\varnothing$ rre avdelinger har dette ikke fungert like godt. Det har derfor vært viktig å informere om at veilederne kan ta kontakt med de kombinerte stillingene ved behov. Behovet for støtte og veiledning er stort, og mange har etter hvert benyttet seg av dette.

Her uttrykte en lærer i kombinert stilling at det er viktig å være til stede i praksis: «Å kunne gripe fatt i utfordrende ting som skjer i praksis, når de skjer, er viktig. Få ordne opp i ting raskt, så de ikke ødelegger god læring eller god veiledning.»

Et av teamene har hatt ansvar for internasjonale studenter som kommer til UiT og har praksisstudier ved UNN. Teamet ivaretar studentene gjennom å sikre engelskspråklige veiledere, hjelper til med organisering og tilrettelegging av praksisstudiene og tar ansvar for at studentene får planer og retningslinjer oversatt til engelsk. Teamet har arrangert kurs for sykepleierveiledere og lærerveiledere, hvor sentrale temaer har vært interkulturell kommunikasjon, kultur, og helseterminologi på engelsk. Formålet med kursene har vært kompetanseheving samt å rekruttere, motivere og trygge veilederne til å ta ansvar for internasjonale studenter.

\section{Forskning, fagutvikling}

Ansatte i kombinerte stillinger har s $\varnothing \mathrm{kt}$ på utviklingsmidler stilt til disposisjon av FUU (FUU er et samarbeidsorgan mellom UNN og Helsefak) for å kunne prøve ut faglige utviklingsprosjekter. Totalt 16 prosjekter har siden oppstarten blitt tildelt midler i størrelsesorden 12 000-82 000 kroner.

Prosjektene har omhandlet beskrivelser av praksis, bruk av nye praksisarenaer, utprøving av nye veiledningsmodeller og tverrprofesjonell samarbeidslæring. Eksempel på sistnevnte er Mäki og Tangens prosjekt med sykepleier- og farmasistudenter ( 19 ) og Cheethams prosjekt med sykepleier- og medisinstudenter (20).

\section{Erfaringer så langt}

\section{Samarbeid}

De kombinerte stillingene har hatt stor betydning for samarbeidet mellom utdanning og praksisfelt ( $\underline{8}$ ), både formelt og uformelt. En sykepleier i kombinert stilling uttrykte det slik: «Samarbeidet med praksisfeltet gir bedre samarbeidsklima og større forståelse for hverandres utfordringer.» 
Vi erfarer at sterkere oppmerksomhet mot kvalitet i praksisstudiet har gjort at sykepleierne i kombinerte stillinger har $\varnothing \mathrm{kt}$ kunnskap om utdanningens innhold, slik at studentenes læringsutbytte og behov for veiledning og vurderingsordning sikres. Lærerne har på sin side blitt bedre kjent med praksisfeltet, og har gjennom undervisningen gjort studentene bedre forberedt til praksisstudiene ( 8 ).

\section{$\equiv$ «Gode mellommenneskelige relasjoner har vist seg å være avgjørende for å utvikle et godt læringsmiljø.»}

Teamene har jobbet mye med planlegging av studentenes praksisstudier og mottak av studenter. Det at studentene føler seg velkomne og blir godt mottatt og fulgt opp, har betydning for læringsmiljøet. Gode mellommenneskelige relasjoner har vist seg å være avgjørende for å utvikle et godt læringsmiljø $(18,21)$. Flere studier understreker også viktigheten av at studentenes praksis planlegges på en slik måte at det etableres strategier og tilnærminger som fremmer studentenes læringsprosess og faglige utbytte (스, 22).

\section{Erfaringsseminar}

Studielederen ved utdanningen har hvert semester arrangert et erfaringsseminar for alle ansatte i kombinerte stillinger. I forkant av seminarene har alle teamene rapportert skriftlig hvilke arbeidsoppgaver de har jobbet med, og delt erfaringer, ideer og refleksjoner. Teamene oppfordres til å planlegge neste semester og nedfelle dette i en egen plan.

Erfaringsseminarene styrker samarbeidet mellom de ansatte både i de enkelte teamene og teamene imellom ( 8). Årlige nettverksseminarer for alle i kombinerte stillinger arrangeres også. Seminarene er viktige for kunnskapsutvikling, erfaringsdeling og samarbeid mellom de ansatte i kombinerte stillinger og mellom profesjonene.

\section{FoU-arbeid}

Fagutvikling og forskning knyttet til studentenes praksisstudier er viktig (23). Teamene initierer slikt arbeid ut fra behov og problemstillinger som reises i praksis, og derfor blir FoU-arbeidet praksisnært. En av sykepleierne oppsummerte det slik: «Mye artig tverrfaglig arbeid, og det er bare fantasien som setter grenser for spennende utviklingsprosjekter.» 
På samme måte som i andre rapporter om kombinerte stillinger, erfarer vi at det er viktig at ledelsen er i dialog med de ansatte, og at prioriteringer av arbeidsoppgaver drøftes ( $\underline{10}, \underline{11}, \underline{12}, \underline{13}, \underline{24})$. Studielederen ved sykepleierutdanningen og representanter fra fag- og forskningsavdelingen ved UNN har vært tett på arbeidet med kombinerte stillinger siden oppstarten.

\section{Konklusjon}

Ordningen med kombinerte stillinger er viktig og bør videref $\varnothing$ res. Praksisprosjektet Kvalitet i praksisstudiene fra 2016 (23) viser at arbeidet vi har gjort i Troms $\varnothing$, er i tråd med nye nasjonale anbefalinger.

Vi støtter også Helsefak og UNNs rapport ( 9), som anbefaler at ordningen utvides til også å gjelde campus i Harstad og Narvik, og at det etableres tilsvarende kombinerte stillinger ved Finnmarkssykehuset og campus Hammerfest.

\section{Referanser}

1. Lov 24. juni $2011 \mathrm{nr} .30$ om kommunale helse- og omsorgstjenester m.m. (helse- og omsorgstjenesteloven). Tilgjengelig fra: https://lovdata.no/dokument/NL/lov/2011-0624-30 (nedlastet 09.01.2018).

2. St.meld. nr. 47 (2008-2009). Samhandlingsreformen: rett behandling - på rett sted - til rett tid. Oslo: Helse- og omsorgsdepartementet; 2009.

3. Meld. St. nr. 13 (2011-2012). Utdanning for velferd Samspill i praksis. Oslo: Kunnskapsdepartementet; 2012.

4. Kunnskapsdepartementet. Rammeplan for sykepleierutdanning. Oslo; 2008.

5. Lov 2. juli 1999 nr. 61 om spesialisthelsetjenesten m.m. (spesialisthelsetjenesteloven). Tilgjengelig fra: https://lovdata.no/dokument/NL/lov/1999-07-02-61? q=spesialisthelsetjenesteloven (nedlastet 24.05.2017).

6. Schreiner A. Kom i gang. Kvalitetsforbedring for leger. Skriftserie for leger: Utdanning og kvalitetsutvikling. Oslo: Den norske lægeforening; 2004. 
7. Konsmo T, de Vibe M, Bakke T, Udness E, Eggesvik S, Norheim G, et al. Modell for kvalitetsforbedring - utvikling og bruk av modellen i praktisk forbedringsarbeid. Rapport 2015.Tilgjengelig fra: https://www.fhi.no/publ/2015/modell-forkvalitetsforbedring--utvikling-og-bruk-av-modellen-ipraktisk-fo/ (nedlastet 15.01.2018).

8. Skaalvik M, Borch I, Hokland K, Aronsen MT, Foss I. Evaluering av ordningen med kombinerte stillinger for helsefaglige utdanninger ved UNN og UiT. 2014. Tilgjengelig fra: http://docplayer.me/4388763-Evaluering-av-ordningenmed-kombinerte-stillinger-for-helsefaglige-utdanninger-vedunn-og-uit.html (nedlastet 13.06.17).

9. Nikolaisen M, Konradsen AH, Barge BSN, Reitan ECK, Tufte-Gerhardsen G, Øien L, et al. Rapport fra arbeidsgruppe om kombinerte stillinger. Upublisert materiale; 2017.

10. Gadgil IE, Grongstad M, Isaksen L, Lyngdal $\varnothing$. Forbedringsforslag av ordningen med kombinerte stillinger. Upublisert materiale; 2015.

11. Skaalvik MW, Henriksen N, Normann HK. The nurse teacher's role in clinical practice - Norwegian nursing students' experiences. A cross-sectional survey. Nordisk sygeplejeforskning. 2015;5(4):356-66.

12. Langeland K, Thoresen L. Lærers følgedag i

sykehuspraksis - for praksisveileders skyld? Vård i Norden. 2013;33(4):19-22.

13. Olsen KB, Knudsen LB. «Også det å se pasienten oppe i alt dette» - En studie av sykepleierstudenters erfaringer med å lære sykepleie i praksisstudier på sykehus. Nordisk sygeplejeforskning. 2015;5(4):315-28.

14. Egilsdòttir H, Fermann T. Kombinasjonsstillinger i praksisstudier. Sykepleien. 2017;3(105):70-3. Tilgjengelig fra: https://sykepleien.no/forskning/2017/02/kombinasjonsstillingeri-praksisstudier (nedlastet 09.01.2018)

15. Lave J, Wenger E. Situated learning: legitimate peripheral participation. Cambridge: Cambridge University Press; 1991. 
16. Breivik S, Tymi A. Hva innebærer systematisk klinisk unders $\varnothing$ kelse i sykepleie? Sykepleien Forskning. 2013;8(4):324-32. Tilgjengelig fra: https://sykepleien.no/forskning/2013/10/hva-innebaerersystematisk-klinisk-undersokelse-i-sykepleie (nedlastet 09.01.2018).

17. Aigeltinger E, Haugan G, Sørlie V. Utfordringer med å veilede sykepleierstudenter i praksisstudier. Sykepleien Forskning. 2012;7(2). Tilgjengelig fra: https://sykepleien.no/forskning/2012/06/utfordringer-medveilede-sykepleierstudenter-i-praksisstudier (nedlastet o8.01.2018).

18. Skaalvik MW. Bedre kvalitetssikring av praksis. Sykepleien. 2015;(4):58-61. Tilgjengelig fra: https://sykepleien.no/forskning/2015/03/evaluering-av-klinisklaeringsmiljo (nedlastet 08.01.2018).

19. Mäki E, Tangen L. Gjennomføring av screeninger i Trygge hender-kampanjen for sykepleierstudenter og farmasistudenter. Universitetet i Troms $\varnothing$ : IHO; 2017.

20. Cheetham NB. Får innsikt i hverandres fag. Sykepleien. 2016;104(9):48-50. Tilgjengelig fra: https://sykepleien.no/forskning/2016/o9/tverrprofesjonelllaering-mellom-sykepleie-og-medisinstudenter (nedlastet 13.06.2017).

21. Levett-Jones T, Lathlean J. «Don't rock the boat»: nursing students' experiences of conformity and compliance. Nurse Educ Today. 2009;29(3):342-9.

22. Solvoll BA, Heggen KM. Teaching and learning care exploring nursing students' clinical practice. Nurse Educ Today. 2010;30(1):73-7.

23. Universitets- og høgskolerådet. Kvalitet i praksisstudiene i helse- og sosialfaglig høyere utdanning: praksisprosjektet. Sluttrapport fra et nasjonalt utviklingsprosjekt gjennomført på oppdrag fra KD i perioden 2014-2015. Oslo; 2016.

24. Mathisen L, Rannem S. Kombinerte stillinger krever aktiv ledelse. Sykepleien. 2016. Tilgjengelig fra: https://sykepleien.no/forskning/2016/11/kombinerte-stillingerkrever-aktiv-ledelse (nedlastet 13.06.2017). 
